https://doi.org/10.31874/2309-1606-2018-22-1-259-269

УДК: 373. 1.

\title{
Світлана ГАНАБА
}

\section{ШКОЛА ЯК СЕРЕДОВИЩЕ РОЗВИТКУ ДИТИНИ}

\author{
Рецензія на книгу: Джон Тейлор Гатто \\ «Зброя масового навчання. Мандрівка \\ вчителя темними світами обов'язкового \\ шкільництва». Переклала 3 англ. Галина \\ Сташків. Львів: Літопис, 2016. - 210 с.
}

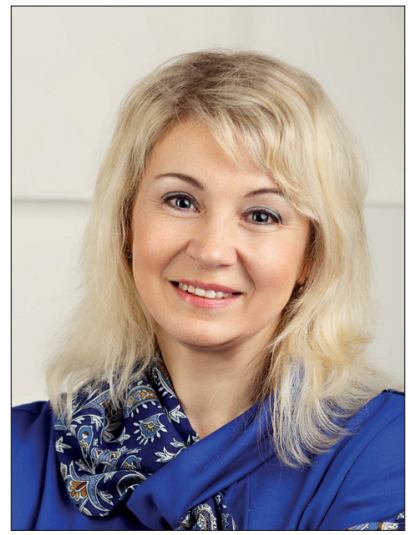

\section{Анотація}

У статті здійснено огляд основних ідей Джкона Гатто у праці «Зброя масового навчання». У книзі акцентується увага на вадах та негараздах сучасного шкільного навчання. Свої міркування автор концентрує на репресивній природi навчання, розглядаючи його як примусовий вишкіл, як вбивчу рутину для школярів. У своїй книзі педагог доходить висновку, що сучасні школи не розвивають, а отуплюють дітей. На сторінках книги Дж. Гатто намічає певні орієнтири розвитку якісної освіти. Засадничою ідеєю у його міркуваннях є розуміння школи як середовища розвитку учнів. Творення себе - ось найголовніше завдання учня в школі. Замість нормативного, універсального, «контрольованого» шкільництва дослідник пропонує освіту з «відкритих джерел». Така освіта грунтується на досвіді, особистих прагненнях й запитаннях тих, хто навчається. Вона надає можливість школяреві керувати процесом отримання знань самостійно.

Ключові слова: освіта, дитина, репресивність навчання, саморозвиток, школа, особисті прагнення.

Освіта є важливим соціокультурним ресурсом суспільного життя й вагомим капіталом розвитку особистості. Завдяки освіті особистість долучається до культурних надбань минулих поколінь, активізує й збагачує свій життєвий досвід, культивуючи особистісні задатки й пошуки власної ідентичності тощо. Використання й, водночас, творення людиною освітнього ресурсу здійснюється відповідно до іiі іманентної природи. Проте особистість не є повністю вільною у виборі власного шляху навчання відповідно до своїх здібностей та уподобань, пошуку способів та форм організації освітньої діяльності тощо. Вона не створює їх на власний розсуд чи за своїм спланованим замислом. Пріоритети та цілі освітнього процесу багато у чому задаються суспільними вимогами та 
інтересами. Йдеться про те, що у реаліях суспільного життя освіта не може уникнути виконання двох своїх покликань - антропологічного та соціального. Між цими освітніми місіями існує певний внутрішній конфлікт. Індикатором посилення чи послаблення цієї напруженості є рівень виконання освітою свого основного призначення, а саме: допомогти й дати можливість людині самовизначитися, дізнатися, хто вона є як особистість, відкрити свої зацікавлення та здібності тощо. За умови орієнтації освіти лише на соціальний запит, а не на інтереси й потреби людини формується культ дисциплінарно невільної освіти. Вона за своєю природою є репресивною, оскільки передбачає атрофію у людини здатності до саморозвитку, поглиблює ризики й загрози здоров'ю тих, хто навчається, робить їх безпорадними, апатичними, асоціальними у вирішенні сучасних проблем. Тому переосмислення й подолання дискримінаційних соціокультурних практик в освіті є однією із нагальних проблем цієї сфери.

Слід зазначити, що у сучасному науковому дискурсі є чимало досліджень, присвячених цій проблематиці. Зокрема, у анти-педагогіці (А. Ілліч), революційній педагогіці (П. Макларен), граничній педагогіці (Г. Жиру), критичній педагогіці (П. Фрейре), феміністських педагогіках тощо представлені різнопланові думки щодо розпізнавання авторитарних тенденцій в освітянській сфері й презентовані конструктивні шляхи їх подолання. Попри відмінність дослідницьких стратегій об’єднавчою позицією цих напрямків є визнання освіти як практики свободи, джерела соціальної трансформації та емансипації людини. Власне у такому річищі написано одне із останніх досліджень Джона Тейлора Гатто (John Taylor Gatto) «Зброя масового навчання. Мандрівка вчителя темними світами обов'язкового шкільництва».

Джон Тейлор Гатто (John Taylor Gatto) - американський письменник й знаний педагог із 30-ти річним стажем, експерт з питань реформування шкільної системи освіти. У своїх численних виступах та низці публікацій він розмірковує про вади та негаразди сучасного шкільного навчання й окреслює шляхи його зміни. На думку дослідника, тотальна експансія сучасної школи позбавляє вільного часу, який необхідний дітям для самостійного й творчого пізнання світу. Замість цього вони навчаються виконувати накази й бути гвинтиками, які чітко функціонують у суспільній машині. Натомість педагог стверджує, що розвиток у дітей допитливості, любові до пригод, життєлюбства, вміння оригінально мислити тощо є можливим лише за умови залучення дітей у реальний світ суспільного життя й надання «кожному школяру свободи, щоб вони могли час від часу ризикувати» (Гатто, 2016: 8). Не дивлячись на те, що у книзі мова йде про навчання в американських школах, усе сказане ав- 
тором дуже нагадує ситуацію, яка є характерною для українських шкіл. Українська система освіти, як і освітні системи інших країн, сформована у полі культурних орієнтирів Просвітництва, на сьогодні практично вичерпала себе та набула кризових ознак. Вона не відповідає реаліям тих трансформаційних процесів, які відбуваються у сучасному світі, не допомагає людині у реалізації їі творчого потенціалу, в отриманні знань та досвіду, необхідних для життя. Розмежованість цілей, змісту, методів і результатів навчання; переважання авторитарних методів викладання; гонитва за знаннями у межах інформаційно-пояснювального підходу; пасивність учнів у сприйнятті предмета, оскільки вони не бачать можливості використання отриманої інформації у своїх майбутніх планах; деперсоналізовані форми контролю, які вимагають головним чином відтворення набутих знань тощо засвідчують необхідність пошуку шляхів реформування української освіти. І у цьому плані дослідження американського педагога є на часі.

На початку книги Дж. Гатто задає смисловий горизонт своїх міркувань, ставлячи запитання: «Чи справді нам потрібна школа?» (Гатто, 2016: 9). При цьому автор має на увазі не ідею відмови від освіти як фундаментальної цінності для людини. Свої міркування він концентрує на репресивній природі навчального процесу, розглядаючи його примусовий вишкіл як вбивчу рутину для школярів: шість уроків на день, п'ять днів на тиждень, дев'ять місяців на рік - упродовж дванадцяти років (Гатто, 2016: 9). На сторінках книги педагог розмірковує над проблемами: який освітній продукт ми хочемо отримати і, взагалі, кого прагнемо виховувати; чи здатний навчальний процес забезпечити творчий розвиток та самовизначення особистості; які механізми примусового вишколу у навчальному процесі калічать уяву та знеохочують дітей критично мислити; як уникнути пастки примусового вишколу й розвинути потенційні здібності учнів тощо.

Загалом він пропонує дещо інший погляд на систему освіти та іiі роль у житті дитини та суспільства. Зокрема, аналізуючи окреслені проблеми Дж. Гатто розмежовує процес власне отримання людиною знань та навчання у школі. У суспільному житті, на його думку, ці процеси виконують кардинально відмінні функції й націлені на різні результати. Так, навчання у школі є реалізацією соціальної місії освіти. Воно залучає людину у певну дисциплінарну матрицю освіти, формуючи у неї комплекс рис та якостей, необхідних та значимих для суспільства. Існування людини для себе самої є вторинним процесом, який підпорядковується суспільним потребам. Якщо навчання у школі - це рух ззовні до середини, з метою моделювання й конструювання своїх учнів відповідно до суспільних вимог, то процес отримання людиною власної освіти - це 
рух зсередини назовні. Цей процес має інший гатунок, оскільки передбачає розвиток та самовибудовування людини. Він відбувається у природний спосіб й ліквідовує те, що обмежувало можливості людини, було перешкодою для її вільного й продуктивного розвитку. Цей процес уособлює екзистенційну місію освіти.

Втілення у навчанні чітких вимог соціуму щодо «виготовлення» людей як певних соціальних персонажів епохи свідчить про репресивність освітнього процесу. Репресивність навчання свого часу грунтовно проаналізував М. Фуко. Він стверджував, що владні відносини у навчальному процесі являють складну конфігурацію стратегій та практик, через які влада проникає у найглибші нюанси людського єства з метою його повної інтеграції у систему контролю (Фуко, 1999). Репресивність освіти має чимало вимірів, частина з яких, приховані. Власне, неочевидність, що містить лише буття-у-можливості, й зумовлює низку загроз та небезпек. Тому неврахування прихованих репресивних практик, сприйняття їх як фантазійних чи віртуальних, викликає негативні наслідки як для людини, так і суспільства. «Те, що існує в потенції як вкорінена в людині екзистенційна можливість, безумовно існує і має всю вагомість реального буття, хоча часто неусвідомленого чи витісненого на периферію самосвідомості та життєвої практики» (Пролеєв, 2007: 20). Зазвичай тим, хто звик до наявного десятиріччями порядку речей важко із середини побачити й проаналізувати ті явища, що є частиною освітньої системи. Дж. Гатто ставить перед собою це нелегке завдання. Мандруючи «темними коридорами обов’язкового шкільництва», що приховують прояви репресивних практик, дослідник не лише їх виявляє, а й детально аналізує й показує вплив на людину. Він стверджує, що вони реалізуються завдяки уніфікації та стандартизації навчального процесу, його побудові за ієрархічним принципом, регламентації поведінки дитини та педагогів й мають на меті «звести якомога більше індивідів до одного безпечного рівня, культивувати та підготувати стандартизованих громадян, придушити розкольництво й оригінальність» (Гатто, 2016:10). Дисциплінування, змагальність, заохочення і покарання, раціональна побудова навчального процесу, відтворення знань через чітко окреслені уміння та навички, предметно-фрагментарне, уніфіковане й стандартизоване конструювання знань є обов'язковими складовими образу освітнього закладу, який плекає інтелектуально несамостійну особистість та підпорядковує їі потребам соціуму, нівелюючи ті цінності та смисли, які співзвучні ії єству.

Відтак задекларовані упродовж останніх століть цілі освіти, а саме: «формування добрих людей, формування добрих громадян, допомога кожній особі розкрити іiі потенціал» (Гатто, 2016: 10), за твердженням 
Дж. Гатто, зводяться нанівець. Вони не співзвучні із тими завданнями та функціями освіти, які реалізуються у цій сфері в останні десятиріччя. Педагог, показуючи відмінність цілей освіти та способів ії реалізації, вибудовує своєрідну концептуальну канву навчального процесу. Даний процес, на його думку, грунтується на низці функцій. Так, функція пристосування (адаптації) цілковито унеможливлює критичне мислення під час навчання й, крім того, практично руйнує уявлення, чому навчати та як навчати. Учні не виявляють ініціативи і чекають, коли вчитель скаже їм, що, як і коли необхідно виконувати. Фактично вони мають просто відтворювати те, що у них вкладають, не виявляючи будь-якої ініціативи, не формулюючи власного бачення й перспектив використання знань у життєвих практиках. До того ж усе, чому навчають дітей, подається поза будь-яким контекстом. Ніщо ні з чим не пов'язане.

Наступна функція передбачає інтегрування, тобто створення «відповідності» дітей щодо певних правил та стандартів, з метою сформувати їх якомога більш подібними й уніфікованими. Люди, які відповідають визначеним критеріям, $є$ передбачуваними, їх поведінка $є$ прогнозованою, ними легко керувати й маніпулювати. Директивна та діагностична функції дозволяють математично та на основі особистих спостережень визначити низку соціометричних даних й окреслити належну соціальну роль учня, зафіксувавши їх у «особових справах». Щойно дітям діагностують їхню «соціальну роль» згідно функції розшарування школярів сортують за цими ролями й навчають суто настільки, наскільки того вимагає їх призначення у соціальній машині. Про особисті уподобання та благо дитини моя взагалі не йде. Наступною $є$ функція добору. Вона передбачає маркування непридатних дітей низькими оцінками, заходами корекції та іншими покараннями для того, щоб їхні однолітки сприймали їх як нижчу касту. Пропедевтична функція заснована на правилах, згідно яких невелику кількість дітей навчатимуть, як керувати та наглядати за іншими, як навмисно затуркувати та позбавляти здатності до опору (Гатто, 2016: 12-13).

Таким чином, школи постають справжніми фабриками з розвитку інфантильності, оскільки намагаються зробити людей більш слухняними, більш обмеженими, більш керованими. Індивідуальність дітей, їх мрії та думки, особисті якості залишаються незатребуваними. У шкільних установах не шукають великих митців, художників, музикантів, лікарів тощо. Навпаки, в освітніх закладах придушують геніальність, оскільки не знають, як їй давати раду. Шкільні установи не плекають таланти та мізки, оскільки вони не потрібні суспільству. Вони орієнтовані не на виробництво, а на споживання готової суми знань та ідей інших. Не навчаючи дітей вчитися, не спонукаючи до творення нового інтелектуально- 
го продукту, вони у кінцевому рахунку виховують людину-споживача й сприяють становленню суспільства споживання. «Зрілість нині витіснено мало не з усіх аспектів нашого життя. Спрощене законодавство щодо розлучень усунуло потребу працювати над стосунками; легкі кредити звільнили нас від потреби контролювати свої видатки; прості відповіді позбавили потреби ставити запитання. Ми стали нацією дітей, що охоче поступаються своїми судженнями та волею перед політичними закликами та комерційними улещуваннями, що їх справді дорослі люди вважали б образою», - пише Дж. Гатто (Гатто, 2016:15).

У своїй книзі Дж. Гатто доходить висновку, що сучасні школи не розвивають, а отуплюють дітей. Однак поняття тупості дослідник розглядає не як просте незнання чи некомпетентність, які можна ліквідувати шляхом отримання знань. В умовах сучасних освітніх реалій, за твердженням науковця, ця категорія перетворюється на відверту дурість, якою нормують навчання задля блага суспільства. Освітні інституції навчають все сприймати на віру, бути безініціативними й залежними від думок чи оцінок інших. Розум школярів «піддається обробці величезними дозами комерційно завареної дезінформації для того, щоб приспати його» (Гатто, 2016: 96). У результаті заклади освіти «ламають» дітей, виготовляючи з них інформаційних зомбі й позбавляючи їх життя, яке сповнене значення та власного сенсу. Схожі думки висловлює британський дослідник проблем філософії освіти К. Робінсон (K. Robinson). Він аналізує традиційну систему освіти як репресивну й стверджує, що вона придушує творчий потенціал дитини, не плекає у неї зацікавленість й допитливість, не у повній мірі враховує особливості ії індивідуальності (Робінсон, 2013).

У ракурсі цих міркувань Дж. Гатто розглядає також проблему репресивного впливу на дитину телебачення та соціальних мереж. Вони, як і освітні заклади, сприяють формуванню апатичного світогляду у дитини, залишаючи їй все менше часу на живе спілкування, розвиток емоційного світу, почуттів та переживань тощо. Телезалежні діти, на думку педагога, є безвідповідальними, підступними, брехливими, інфантильними, оскільки їм бракує власної важливої мети. Споживаючи з екранів/моніторів надмір вигаданих історій, наслідуючи багатьом людям, які вдають із себе когось іншого, слухаючи надмір різних пояснень, вони втрачають здатність поводитися природно, цілісно, тобто рости (Гатто, 2016: 100). Прикувавши тіло й розум до екрану/монітору, діти втрачають чимало дорогоцінного часу, який є необхідним для спроб та помилок у набутті досвіду й індивідуального зростання. Вони не дорослішають, оскільки не лише полишенні власної життєвої мети, а й не завжди здатні нести 
відповідальність у вирішенні проблем, боротися зі своїми слабостями та розвивати серце, розум і дух.

Який вихід із окресленої ситуації пропонує дослідник? На сторінках книги він не дає готових рішень і не формує оптимістичних прогнозів відносно майбутнього шкіл. Педагог лише намічає певні орієнтири розвитку якісної, ефективної освіти, яка б спонукала у школярів розвиток живого інтересу до знань. Засадничою ідеєю у його міркуваннях є розуміння школи як середовища для розвитку та самозростання учнів. Творення себе - ось найголовніше завдання учня в школі. «Справжня освіта може початися лише на підвалинах самоусвідомлення. Пізнайте істину про себе, інакше будете просто жалюгідним людським ресурсом. Ваше життя втратить сенс», - наголошує Дж. Гатто (Гатто, 2016: 73). Процес пізнання себе є можливим, за твердженням дослідника, за умови плекання освіченого розуму. Що вкладає у дане поняття американський педагог? На його думку, освічений розум - це «розум зі зв’язками, пов'язаний із цілим розмаїттям усіляких людських стилів (а не стерильними шкільними еквівалентами), пов'язаний із багатоманітними різновидами складного досвіду - іноді потенційно психологічно або фізично ризикованими (на відміну від голого досвіду шкільних дзвінків у в’язниці у відміряний час)» (Гатто, 2016: 135). На сторінках книги Дж. Гатто виокремлює характерні риси такого розуму, а саме: 1) здатність ставити складні запитання про факти й події; 2) здатність самостійно визначати проблеми, уникати рабської залежності від офіційних визначень; 3) здатність передивлятися масу недоречної інформації та швидко відокремлювати зерно від полови; 4) здатність формулювати поняття; 5) здатність трансформувати інформацію у нові структури, уможливлюючи погляд із нетрадиційної позиції; 6) наявність гнучкого розуму, спроможного перемикатися на різні типи мислення: дедуктивне, індуктивне, евристичне, інтуїтивне тощо; 7) легкість співпраці з партнерами або в командах; 8) вправність в обговоренні питань, проблем або прийомів; 9) красномовство, здатність переконати інших у правильності свого курсу (Гатто, 2016: 83). Плекання у процесі навчання освіченого розуму $\epsilon$ неодмінною умовою якісної освіти й успішного життя в умовах мінливого світу. Школярі насолоджуються здатністю створювати нові ідеї, досвід й речі, відкриваючи істину через докази, а не запам'ятовуючи думки інших. Таке навчання відбувається не за формулою «Дозвольте іншим подумати за вас!», а під девізом «Не вірте нікому на слово, думайте самостійно!» (Гатто, 2016: 125). Як результат у шкільні кімнати повертається живий дух справжнього життя. У цьому процесі Дж. Гатто радить спонукати дітей братися до складного - дорослого - матеріалу з історії, літератури, філософії, музики, мистецтва, економіки, теології, - всьо- 
го того, чого шкільні вчителі всіляко намагаються уникати. Дослідник також закликає випробувати дітей усамітненням, щоб вони навчились насолоджуватися власним товариством, виробили здатність вести внутрішній діалог. «Люди привчені боятися усамітнення; вони постійно шукають компанії через телебачення, комп'ютер, мобільний телефон, через поверхову дружбу, що швидко набувається і легко забувається. У ваших дітей має бути життя, сповнене значення, і вони можуть його мати», - пише педагог (Гатто, 2016: 15).

Позбутися старих освітніх структур й допомогти дітям справді навчатися, а не відбувати час у школі, на переконання Дж. Гатто, допоможе також освіта з «відкритих джерел». Вона передбачає відхід від нормативного, універсального, «контрольованого» шкільництва. За своєю природою така освіта є індивідуалізованою, оскільки надає можливість школяреві керувати процесом отримання знань самостійно. Вона не є дисциплінарно центричною, позбавлена страхів, апатії та байдужості учнів й грунтується на досвіді, особистих прагненнях й запитаннях тих, хто навчається. Освіта позбавляється мурів, оскільки навчальний процес відбувається всюди: на фермах, на кораблях, у приватних домівках, у церквах, у тисячах інших приміщень тощо. Він перегукується з проблемами школярів й спирається на їх щоденний досвід. На думку дослідника, освіта 3 «відкритих джерел» передбачає, «що все, що існує під сонцем, може бути ймовірним відправним пунктом на шляху до самовладання та хорошого життя: робота в гаражі, покер, стриптиз, будь-що. I всі, кого ви зустрічаєте, потенційно можуть бути вчителями: автомеханіки, шулери, стриптизерки, автогонщики, будь-Хто» (Гатто, 2016: 45). Усі, кому є що запропонувати, хто має знання й досвід й готовий ним поділитися, можуть навчати. У цьому способі освіти вчителювання є функцією, а не професією. У ролі викладачів можуть виступати й школярі, за умови, що мають певні знання чи досвід з певної проблеми. У такому навчанні вони є активними ініціаторами й учасниками освітнього процесу, створюючи власний сценарій своєї освіти. Обмежити таке навчання будь-якими приписами чи алгоритмами означає зруйнувати його суть та призначення, його особливості, затиснувши у міцні лещата офіціозу. Інтерес, свобода, ініціатива - це те, що має стати основою навчального процесу. Звернення до досвіду, урахування практик повсякденного життя дозволить розглядати освіту як засіб особистісного зростання та плекання самобутності людини, розвитку іiі креативних та вітальних можливостей. «Зацікавитися чимось означає сприйняти річ як входження в ситуацію, що постійно розвивається, а не трактується ізольовано», - стверджує Дж. Д’юї (J. Dewey) (Д’юї, 2003: 110). 
Попри те, що більшу частину життя сучасні діти проводять у школі, не варто покладатися на переконання, що освітні установи здатні виконати функцію їх навчання й виховання та підготовки до життя у сучасних реаліях. Хибною є думка, що саме школа робить людину людиною. Так чи інакше, школа у першу чергу виконує суспільне замовлення, готуючи дітей до виконання своїх потреб та інтересів. Тому батьки мають звертати увагу на те, чому навчають дитину у школі. Вони мають менше покладатися на освітні установи у вихованні, більше уваги приділяти дитині, прислухатися до їі потреб й жити з нею спільним життям.

Ідеї, презентовані у книзі Дж. Гатто, є не радикальними, а радше фундаментальними для будь-якого процесу пізнання. Вони спрямовані на те, щоб спонукати якомога більшу кількість людей вдатися до змін в освітній сфері. Вони є релевантними для української освіти, оскільки сприятимуть розвитку індивідуальної свободи тих, хто навчається, привчатимуть їх до життя в умовах свободи і повної відповідальності за свої рішення і вчинки. Ідеї педагога є цінними для нас і тим, що дозволяють освіті виконати свою особливу історичну місію - стати вирішальним чинником трансформації суспільства.

\section{Посилання}

Гатто Дж. Тейлор (2016). Зброя масового навчання. Мандрівка шкільного вчителя темними світами обов'язкового шкільництва [пер. 3 англ. Галина Сташків]. Львів: Літопис.

Д’юї Дж. (2003). Демократія і освіта. Львів: Літопис.

Пролеєв С. (2007). Репресивність освіти: вимушена необхідність чи владні зазіхання соціуму? Філософія освіти. Philosophy of Education, 1(7), 17 - 27.

Робинсон К. (2013). Образование против таланта. Пер. с англ. Наталии Макаровой. М.: Из-во «Манн, Иванов и Фербер», Изд-во «Эксмо».

Фуко М. (1999). Надзирать и наказывать. Пер. с франц. В. Наумова по ред. И. Борисовой. M.: Ad Marginem.

\section{References}

Gatto, J. Taylor (2016). Weapons of mass training. The journey of a school teacher by dark worlds of compulsory schooling. Translation from English by Galina Stashkiv. Lviv: Litopus [In Ukrainian].

Dewey, J. (2003). Democracy and education. Lviv: Litopys [In Ukrainan].

Proleiev, S. (2007). Repression of Education: Forced NeceSSity or Socium's Power Intentions? Filosofiya osvity. Philosophy of Education, 1(7), 17 - 27 [In Ukrainan].

Robinson, K. (2013). Education against Talent. Translation from English by Natalia Makarova. Moskow: Publishing house "Mann, Ivanov and Ferber", Publishing House "Exmo" [In Russian].

Foucault, M. (1999). Supervise and punish. Trans. from French by V. Naumov, ed. I. Borisova. Moskow: Ad Marginem [In Russian]. 
Светлана Ганаба. Школа как среда развития ребенка

Рецензия на книгу: Джон Тейлор Гатто «Оружие массового обучения. Путешествие учителя темными мирами обязательного школьного образования»

В статье рассмотрены основные идеи Джона Гатто «Оружие массового обучения». В книге акцентируется внимание на недостатках и проблемах современного школьного образования. Свои рассуждения автор концентрирует на репрессивной природе обучения, рассматривая его как принудительное, как убийственную рутину для школьников. В своей книге педагог делает вывод, что современные школы не развивают, а оглупляют детей. На страницах книги Дж. Гатто намечает определенные ориентиры развития качественного образования. Основополагающей идеей в его рассуждениях является понимание школы как среды развития учащихся. Создание себя вот главная задача ученика в школе. Вместо нормативного, универсального, «контролированного» школой исследователь предлагает образование с «отрытых источников». Такое образование основывается на опыте, личных стремлениях и вопросах учащихся. Оно дает возможность школьнику управлять процессом получения знаний самостоятельно.

Ключевые слова: образование, ребенок, репрессивность обучения, саморазвитие, личные стремления.

\section{Svitlana Hanaba. School as environment for child's development}

Book review: Gatto, J. Taylor "Weapons of mass training. The journey of a school teacher by dark worlds of compulsory schooling"

The review of findamental ideas based upon "Weapons of mass instruction" by John Getto is presented in this article. Attention is drawn to defects and troubles of contemporary school studying. The author's speculation is concentrated on repressive gist of teaching, which is considered as compulsory discipline and killer routine for pupils. Schools are genuine factories for the development of inflammation. Individuality of children, their dreams and thoughts, personal qualities remain unclaimed. Genius is suppressed in educational institutions because teachers do not know how to manage with it. The pedagogue comes up with the idea that up-to-date schools make children stupid instead of giving them the possibility to develop. John Gatto point out several tips for powerful progress of qualitative education. The cornerstone of his cogitation is considering school as environment for child's development. Creating yourself is the most significant task for the pupil. The researcher suggests "education of accessible sources" instead of normative, universal, "controlled" schooling. Students get the ability to create new ideas, experiences, things, revealing the truth through evidence, and not remembering the thoughts of other people. In this way of teaching, teaching is a function, not a profession. Teachers can also act as students, provided them to have certain knowledge or experience of the problem. In such a study, they are active initiators and participants in the educational process, creating their own scenario 
of their education. To limit such training to any requirements or algorithms means to destroy its essence and purpose, to cling to the strong grip of an official position. Such education is based upon experience, individual ambitions and questions. It gives an opportunity to take control of studying process on pupil's own. The ideas presented in the book by J. Gatto are not radical, but rather fundamental to any process of cognition. They are aimed to encourage as many people as possible and to make changes in education. These ideas and thoughts are important for Ukrainian education, as they will promote the development of the individual freedom of those who want to learn, bring them to life in the situation of freedom and full responsibility for their decisions and deeds. The ideas of the teacher are valuable for us and for allowing the education to fulfill its special historical mission - to become a decisive factor in the transformation of society.

Key words: education, the child, repression of schooling, self-development, school, individual ambitions.

Світлана Ганаба - доктор філософських наук, доцент, доцент кафедри філософських дисциплін Кам'янець-Подільського національного університету імені Івана Огієнка.

E-mail: sveta_ganaba@ukr.net

Svitlana Hanaba - Doctor of philosophical sciences, Associate Professor, Associate Professor of the Department of Philosophy Kamyanets-Podilsky Ivan Ohienko National University, Ukraine.

E-mail: sveta_ganaba@ukr.net 